\title{
The Effect of Predict-Observe-Explain Strategy on Learners' Misconceptions about Dissolved Salts
}

\author{
Israel Kibirige \\ Joseph Osodo \\ Kedibone Magdeline Tlala \\ University of Limpopo, Polokwane, South Africa \\ Email: Israel.Kibirige@ul.ac.za
}

\section{Doi:10.5901/mjss.2014.v5n4p300}

\begin{abstract}
The effect of teaching and learning strategies on learners' performance is important in science education. This study explored the effect of the Predict-Observe-Explain (POE) strategy on Grade 10 Physical Sciences learners' misconceptions on how salt dissolves in water. A quasi-experimental design was employed in collecting data from South Africa. A t-test and Analysis of Covariance (ANCOVA) were used to analyse the data. The results show that learners in the experimental group (EG) taught using POE performed better in the post-test than their counterparts in the control group (CG) taught using traditional methods. Also, two new misconceptions were identified, namely: 1) salts dissolve in water when it is in 'fine' grains; and, 2) solid sodium chloride is not an ionic compound. These results highlight the need for educators and curriculum developers to include various elements of POE in the curriculum as a model for conceptual change in teaching science.
\end{abstract}

Keywords: Misconceptions, Science, Education, Salts

\section{Introduction}

Curriculum change is worldwide phenomenon and many countries see it as a way to improve the quality of teaching and learning (Brodie, Lelliott, \& Davis, 2002; de la Harpe, \& Thomas, 2009; Picower, 2012; Willink \& Jacobs, 2013; Picower, 2013). In order to meet change different approaches are used such as: academics and the use of communities of practice (Wenger, 1998) as well as distributed leadership (Spillane, 2005). This may call for action on the part of institutions and individual academics (Holdsworth, Bekessy, Mnguni, Hayles, Thomas, 2006). In line with such a global move South Africa introduced the National Curriculum Statements (NCS) was introduced in South Africa as a way of implementing the Outcomes Based Education (OBE) approach which was first introduced in Grade 1 in 1998. The curriculum policy presents what is to be taught, learnt and assessed in all schools (Department of Education, DoE, 2003). The curriculum was developed to uphold constitutional and democratic values in order to provide quality education. Despite its introduction, the teaching of sciences in South Africa is challenged by the paucity of qualified educators in most rural schools. As a result, learners are always taught by educators who are not qualified in the discipline (Mpofu, 2006). This challenge creates many problems to learners, such as inadequacy in scientific knowledge, skills, values, and attitudes. The inadequacy manifests itself in persistent misconceptions (Kurt et al., 2013) held by learners about some science concepts, resulting in learners' poor performance in science (Svandova, 2013).

Studies on learners' comprehension of science concepts indicate that learners had poor understanding (Ogunniyi, 1999; Koba \& Tweed, 2009; Svandova, 2013; Sesen, 2013). Research from South Africa show that it is important for first year science learners at university level to have a requisite understanding of basic science concepts from Grade 12 class (Mumba, Rollnick \& White, 2002); Potgieter, Rogan \& Howie, 2005). These studies further indicated that Grade 12 learners were inadequately prepared for first year chemistry at the university in terms of conceptual understanding. In addition, many learners encounter problems in understanding science concepts because of their naivety (ibid) concerning chemistry topics. Among other science concepts, Grade 10 science learners experience difficulties in understanding how salts dissolve in water (Pers. Obs.). Furthermore, they do not understand the particulate theory of matter and the polar nature of water. Learners' lack of understanding may be attributed to methods educators use to teach science concepts (Auwal, 2013; Kurt et al., 2013). This calls for a learner-centred approach to focus on conceptual 
change and improve their understanding.

This study explored the use of Conceptual Change Model (CCM) and in particular the 'Predict-Observe-Explain' (POE) strategy as part of CCM was used to identify and to overcome learners' misconceptions about dissolved salts. The NCS encourages learner-centred and activity-based strategies with a view of nurturing learners' personal growth (DoE, 2003). The POE was adopted in this study because it enables learners to hypothesize, test their hypotheses and explain observations. Learners' participation throughout the lesson is characterized by predicting, observing and explaining the learning processes (White \& Gunstone, 1992; Assessment Resource Banks, 2007; Kala et al., 2013). Also, POE is important as it is used to find out learners' prior knowledge and thought processes. This information helps educators to identify learners' misconceptions about science and find sustainable solutions to overcome such misconceptions.

Science learners need to have adequate understanding of the basic science concepts (Potgieter et al., 2005; Kurt et al., 2013) if their misconceptions are to be minimized. A review of the literature revealed that there is limited attention on use of POE strategy on learners' misconceptions about dissolved salts, especially from a developing world. Therefore, the purpose of this study was to explore the effect of the POE strategy on learners' misconceptions about dissolved salts, such as Nitrates, Potassium, Sodium and Ammonium salts, among others. The study was guided by the following research question. What effect would POE strategy have on learners' misconceptions about dissolved salts?

\section{Literature Review}

For learning to take place, the role of the learners to construct knowledge is vital. The educator needs to act as a facilitator and create conducive learning environments (Richmond \& Cummings, 2005). Learners come to class with knowledge which may or may not be compatible with the scientific conceptions (Koba \& Tweed, 2009; Parker et al., 2012; Svandova, 2013; Sesen, 2013). Usually, the prior knowledge is acquired through learners' experiences and may be modified throughout the process of learning. During this process, learners may become dissatisfied with their existing knowledge and find the new knowledge plausible, intelligible and fruitful (Posner et al., 1982; Tanner \& Allen, 2005; Svandova, 2013). Depending on the success of the learning process, learners may accommodate, assimilate or reject the new knowledge. According to Posner et al. (1982) and Hewson's (1981) learning is not only considered as the creation of knowledge, but also involves existing knowledge as the basis of new knowledge. For the prior and new knowledge to be reconciled, some conceptions may be rejected while others may be accepted. Hewson and Hewson (2003) stress that for a new conception to be integrated into the existing knowledge, it needs to be intelligible. Conceptual change encourages educators to consider learners' prior knowledge and assist them to find the subject matter plausible and fruitful. In order to achieve this, a variety of teaching strategies should be used. Nevertheless, what is intelligible, plausible and fruitful to one learner might not be to another. Therefore, there is a need to view the process of using POE in learners' contexts.

To foster understanding of basic science concepts, there is need for educators to recognise learners' initial behaviour and modify their teaching styles accordingly. This can be done by investigating learners' science concepts (Walker, 2001; Sesen, 2013). Educators should be aware of what learners think and know about concepts, some of which may contradict science concepts (Duit, Treagust \& Mansfield, 1996; Kurt et al., 2013; Sesen, 2013). Thus, educators need to decide on the methods to use in order to reveal learners misconceptions. The role of the learner is to "construct the knowledge" while the educator creates a positive learning environment and facilitates the process (Arizona Facilities Council, 2000; Richmond \& Cummings, 2005). The learner actively constructs new knowledge from their physical and mental experiences and interactions with the environment (Lee, 2002). Hence, critical and creative thinking should be encouraged by educators through a learner-centred approach.

\section{Methodology}

\subsection{Research Design}

The study employed a pre-and post-test quasi-experimental design in collecting data from learners of similar socioeconomic backgrounds. This design was chosen because it would allow the researchers to compare the performance of two groups after using POE strategy and the traditional teaching approach. 


\subsection{Sample}

The sample consisted of 93 Grade 10 Physical Sciences learners from two neighbouring schools (coded as A and B) in a rural setting in Moutse West circuit in Limpopo Province, South Africa. The ages of the learners ranged from 16 to 20 years. Forty nine (49) learners (31 males and 18 females) were from school $A$ and acted as the experimental group (EG) whereas the control group (CG) consisted of 44 learners (18 males and 26 females) from school B. The learners were purposively sampled. Having been drawn from the same geographical set up, the learners were of the same sociocultural practices.

\subsection{Instruments}

Achievement Test (AT) was used as pre- and post-test instrument. It was administered to both groups before the intervention, to determine their level of understanding of the dissolved salts and to determine learners' conceptions about dissolved salts. After the intervention, a similar post-test was given to all learners in both groups to determine the level of achievement. The AT developed by Brookes et al. (2005) was modified and used to measure the level of understanding of the dissolved salts among both EG and CG. The AT consisted of three questions. Question one consisted of five statements which learners had to classify as either true or false. Question two consisted of nine multiple questions which were used as a diagnostic tool in the design of the teaching and learning materials in addressing misconceptions based on prior knowledge. Question three had two open-ended questions to reveal learners' views on how salts dissolve in water (Appendix 1). Also, Instructional materials used for EG were aimed at addressing misconceptions learners have and to develop scientific conceptual understanding about the dissolved salts. Materials consisted of three worksheets on: how salts are formed, ionisation of salts, and how salts dissolve in water (Appendix 2).

For face validity, three Physical Sciences experts (two Physical Sciences educators and one researcher) examined the instruments with specific reference to Mpofu's (2006) criteria: suitability of the language used to the targeted group; structure and clarity of the questions; and checked if the content was relevant to what would be measured. For reliability, the instruments were piloted over a period of two weeks. Grade 10 learners of a school which was not part of the sample was used. Any questions that were not clear were changed to reduce ambiguity.

A quasi-experimental design was used, where the EG used POE strategy during treatment and the CG used the traditional lecture method. Before the start of the study, both groups wrote a pre-test using the AT to determine science baseline knowledge. Both the groups were then taught similar content over the same time interval (one hour period per contact session for five weeks). After the intervention, both groups wrote a similar post-test. Data were analysed using a T-test to determine statistical differences in learners' achievements for the two groups and the two teaching methods. In addition, Analysis of Co-Variance (ANCOVA) with the pre-test as a covariate was employed to reduce the variation due to error that might have occurred prior to intervention.

\section{Results}

The pre-test revealed a number of misconceptions held by learners in both groups: learners believed that salts 'disappear' when dissolved in water (37\% of the responses in the $80 \%$ from the pre-test) and that salt 'melts' when dissolved in water (27\% of the responses in the $80 \%$ from the pre-test). During the study, two new misconceptions were identified, namely: 1) salts dissolve in water when it is in 'fine' grains; and, 2) solid sodium chloride is not an ionic compound. The results (Table 1 ) reveal that there was no significant difference between the pre-test achievement scores of the CG and EG for questions (Appendix 2). The $p$ value for these questions was greater than 0.05 .

Table 1: Achievement Test Scores from Pre-test of CG and EG

\begin{tabular}{|c|c|c|c|c|}
\hline Question & Pre-test & Mean & SD & $\boldsymbol{P}$ \\
\hline \multirow{2}{*}{1.1.} & Control & 0.50 & 0.51 & \multirow{2}{*}{0.39} \\
\cline { 2 - 4 } & Experimental & 0.53 & 0.50 & \\
\hline \multirow{2}{*}{1.2.} & Control & 0.23 & 0.48 & \multirow{2}{*}{$0.00^{*}$} \\
\cline { 2 - 4 } & Experimental & 0.55 & 0.54 & \\
\hline \multirow{2}{*}{1.3.} & Control & 0.89 & 0.32 & \multirow{2}{*}{0.34} \\
\cline { 2 - 4 } & Experimental & 0.86 & 0.35 & \\
\hline \multirow{2}{*}{1.4.} & Control & 0.77 & 0.42 & \multirow{2}{*}{$0.03^{*}$} \\
\cline { 2 - 4 } & Experimental & 0.59 & 0.50 & \\
\hline
\end{tabular}


* Significant at $<0.05$

\begin{tabular}{|c|c|c|c|c|}
\hline \multirow{2}{*}{1.5.} & Control & 0.70 & 0.46 & \multirow{2}{*}{0.29} \\
\hline & Experimental & 0.76 & 0.43 & \\
\hline \multirow{2}{*}{2.1.} & Control & 0.45 & 0.50 & \multirow{2}{*}{0.05} \\
\hline & Experimental & 0.29 & 0.46 & \\
\hline \multirow{2}{*}{2.2} & Control & 0.80 & 0.41 & \multirow{2}{*}{0.19} \\
\hline & Experimental & 0.71 & 0.46 & \\
\hline \multirow{2}{*}{ 2.3. } & Control & 0.43 & 0.50 & \multirow{2}{*}{0.36} \\
\hline & Experimental & 0.47 & 0.50 & \\
\hline \multirow{2}{*}{2.4} & Control & 0.59 & 0.50 & \multirow{2}{*}{0.34} \\
\hline & Experimental & 0.63 & 0.49 & \\
\hline \multirow{2}{*}{2.5} & Control & 0.41 & 0.50 & \multirow{2}{*}{0.07} \\
\hline & Experimental & 0.27 & 0.45 & \\
\hline \multirow{2}{*}{2.6} & Control & 0.27 & 0.45 & \multirow{2}{*}{$0.04^{*}$} \\
\hline & Experimental & 0.24 & 0.43 & \\
\hline \multirow{2}{*}{2.7} & Control & 0.25 & 0.44 & \multirow{2}{*}{0.15} \\
\hline & Experimental & 0.16 & 0.37 & \\
\hline \multirow{2}{*}{2.8} & Control & 0.20 & 0.41 & \multirow{2}{*}{0.41} \\
\hline & Experimental & 0.22 & 0.42 & \\
\hline \multirow{2}{*}{3.1} & Control & 0.00 & 0.00 & \multirow{2}{*}{ \#\# } \\
\hline & Experimental & 0.00 & 0.00 & \\
\hline \multirow{2}{*}{3.2.} & Control & 0.00 & 0.00 & \multirow[b]{2}{*}{ \#\# } \\
\hline & Experimental & 0.00 & 0.00 & \\
\hline
\end{tabular}

\#\# There was zero achievement in the test that cannot be tested using t-test

After 5 weeks of intervention, a post-test was conducted in EG and CG in order to identify significant differences in the achievement of learners of the two groups (Table 2).

Table 2: Achievement Test Scores from Post-test of CG and EG

\begin{tabular}{|c|c|c|c|c|}
\hline Question & Post-test & Mean & SD & $P$ \\
\hline \multirow{2}{*}{1.1} & Control & 0.64 & 0.49 & \multirow{2}{*}{$0.00^{*}$} \\
\hline & Experimental & 0.90 & 0.31 & \\
\hline \multirow{2}{*}{1.2} & Control & 0.23 & 0.48 & \multirow{2}{*}{$0.00^{*}$} \\
\hline & Experimental & 0.55 & 0.54 & \\
\hline \multirow{2}{*}{1.3} & Control & 0.77 & 0.42 & \multirow{2}{*}{$0.00^{*}$} \\
\hline & Experimental & 0.96 & 0.20 & \\
\hline \multirow{2}{*}{1.4} & Control & 0.77 & 0.42 & \multirow{2}{*}{$0.03^{*}$} \\
\hline & Experimental & 0.59 & 0.50 & \\
\hline \multirow{2}{*}{1.5} & Control & 0.52 & 0.51 & \multirow{2}{*}{0.00} \\
\hline & Experimental & 0.80 & 0.41 & \\
\hline \multirow{2}{*}{2.1} & Control & 0.39 & 0.49 & \multirow{2}{*}{$0.00^{*}$} \\
\hline & Experimental & 0.88 & 0.33 & \\
\hline \multirow{2}{*}{2.2} & Control & 0.82 & 0.39 & \multirow{2}{*}{$0.01^{*}$} \\
\hline & Experimental & 0.96 & 0.20 & \\
\hline \multirow{2}{*}{2.3} & Control & 0.55 & 0.50 & \multirow{2}{*}{$0.00^{*}$} \\
\hline & Experimental & 0.84 & 0.37 & \\
\hline \multirow{2}{*}{2.4} & Control & 0.52 & 0.51 & \multirow{2}{*}{$0.00^{*}$} \\
\hline & Experimental & 0.86 & 0.35 & \\
\hline \multirow[b]{2}{*}{2.5} & Control & 0.27 & 0.45 & \multirow{2}{*}{0.45} \\
\hline & Experimental & 0.29 & 0.46 & \\
\hline \multirow{2}{*}{2.6} & Control & 0.27 & 0.45 & \multirow[b]{2}{*}{$0.04^{*}$} \\
\hline & Experimental & 0.24 & 0.43 & \\
\hline \multirow{2}{*}{2.7} & Control & 0.59 & 0.50 & \multirow{2}{*}{$0.01^{*}$} \\
\hline & Experimental & 0.82 & 0.39 & \\
\hline \multirow{2}{*}{2.8} & Control & 0.30 & 0.46 & \multirow[b]{2}{*}{0.39} \\
\hline & Experimental & 0.33 & 0.63 & \\
\hline
\end{tabular}




\begin{tabular}{|c|c|c|c|c|c|}
\hline \multirow{2}{*}{3.1} & Control & 0.00 & 0.00 & \multirow{2}{*}{$0,00 *$} \\
\cline { 2 - 4 } & \multirow{2}{*}{3.2} & Experimental & 0.22 & 0.42 & \\
\cline { 3 - 4 } & Control & 0.00 & 0.00 & \multirow{2}{*}{$0.01^{*}$} \\
\hline
\end{tabular}

The results in Table 2 show that learner's achievement in question 2.5 and 2.8 were not significantly different for the two groups $(p>0$. 05). This represents $13.30 \%$ of the total questions learners attempted compared to $86.70 \%$ questions in which achievement was significantly different $(p<0.05)$. Generally, in 12 cases, the mean scores of the EG were higher than that of the CG with exception of question 1.4, where the mean scores of the EG was lower. The overall post-test results for both CG and EG were also conducted using a t-test (Table 3).

Table 3: Overall Post-test Results from both CG and EG

\begin{tabular}{|c|c|c|c|c|c|c|}
\hline Group & Number & Mean & SD & Df & T-test & $\boldsymbol{P}$ \\
\hline Control & 44 & 20.87 & 12.31 & 43 & \multirow{2}{*}{2.62} & \multirow{2}{*}{$0.00^{*}$} \\
\hline Experimental & 49 & 34.07 & 15.12 & 48 & & \\
\hline
\end{tabular}

* Significant $p<0.05$

Table 3 shows that the achievement of the EG after treatment (mean 34. $07 \pm 15.12 \mathrm{SD}$ ) was higher than the CG (mean 20. $87 \pm 12.31 \mathrm{SD})$. These means were significantly different $(t=2.62 ; p<0.05)$.

In order to ascertain whether the intervention had an effect, ANCOVA was used on control and experimental preand post-tests. ANCOVA summary results indicate that for experimental group (SS 57, $37 \pm 13,38 \mathrm{~F}$ and $\mathrm{P}<0.05$ ) and for control group (SS 6. $34 \pm 1,49 \mathrm{~F}$ and $\mathrm{P}<0.23$ ) (Table 4).

Table 4: ANCOVA Summary of Pre- and Post-Test Scores of CG and EG

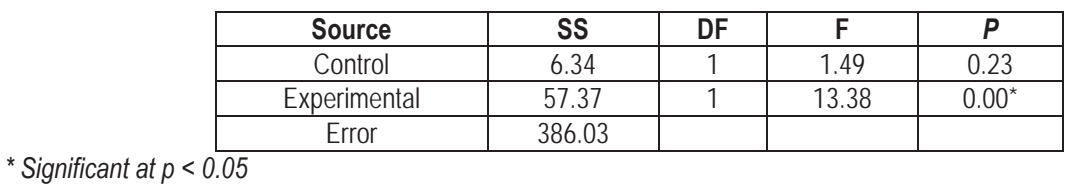

\section{Discussion}

The EG was exposed to POE teaching strategy while the CG was exposed to traditional teaching methods. The study aimed at finding out the effect of POE strategy on learners' performance compared to traditional strategies. The results show that the EG outperformed the CG (Table 3 and 4). Also, the understanding of scientific concepts regarding dissolving of salts differed significantly between learners taught using POE and those taught using traditional strategies. This significant difference is evident from the t-test in Tables 1 and 2 where the mean of CG (Mean $0.00 \pm 0.00 S D$ ) in both questions while in EG the means are (Mean $0.22 \pm 0.42$ ) and (Mean $0.01 \pm 0.3 \mathrm{SD}$ ), respectively. The differences in mean scores obtained by the two groups suggest that POE learners performed better. Thus, the POE approach was able to enhance learners' performance. POE emphasises the use of learner's prior knowledge as the basis of their learning. The importance of learner's prior knowledge is also emphasised by Piaget (1970) and Vygotsky (1986) in social constructivism where the learner is the constructor of new knowledge and active participant throughout their learning processes. The success of POE is viewed as a strategy which takes into consideration the constructivist approach that includes reflective teaching processes and active participation unlike the traditional approach which emphasises chalk and talk (Kasanda et al., 2003). To assist learners to realise and abandon their misconceptions, a learner-centred activity-based strategy was used in the EG as a package of POE. This strategy is also emphasised by the NCS, which encourages learner-centred and activity-based strategies rather than educator-centred activities (DoE, 2003). In POE, learner-centred teaching acknowledges the social construction of knowledge and the basis of all learning, that is, 'learner's prior knowledge'. In this study both prior knowledge, group work and class discussions were incorporated. On the other hand, the traditional teaching strategy used by the CG was educator-centred and learners were mostly passive during the learning process. This result is in agreement with that of Sesen (2013) that diagnosed pre-service science 
teachers' understanding of chemistry concepts using computer-mediated POE tasks and found out that it was an effective method to diagnose students' understanding.

Judging from the mean values, the results of the two groups were not significantly different before the intervention ( $p>0.00$ ) in $80 \%$ of the questions. The pre-test misconceptions held by learners in both groups are similar to those found by Piaget and Inhelder (1974) in their study conducted of a child's construction of quantities and similar to Cosgrove and Osborne's (1981) study regarding physical change. The same misconceptions were also found by Hapkiewicz (1999) in his study of common physical science misconceptions.

From the post-test results (Table 3), learners achievement in $73.3 \%$ of the questions were significantly different ( $p$ $<0.05$ ) in the EG which implies that learners had acquired the right science concepts whereas learners achievement in $13.3 \%$ of the questions in the CG exhibited misconceptions. These findings agree with that of Hewson and Hewson (2003); Hubber (2005) and Demircioglu et al. (2005) that though a variety of teaching methods are used to minimize learners' misconceptions, not all learners abandon their misconceptions. Also, the two new misconceptions suggest that POE was effective in identifying misconceptions, at least, in this study.

The achievement of the EG and CG from pre-test results were not significantly different which suggest that the two groups had similar understanding of concepts. Conversely, results from the post-test after the treatment revealed significant differences. The EG had a higher mean $(34.07 \pm 15.12 \mathrm{SD})$ than the CG $(20.87 \pm 12.31 \mathrm{SD})(t=2.62 ; p<$ $0.05)$, suggesting that the EG had better understanding regarding dissolving of salts. The ANCOVA results from the posttest scores for both groups (Table 4) show that the EG post-test results were significantly different (SS $57.37 \pm 13.38 \mathrm{~F}$ and $p=0.0004$ ), while the CG post-test was not significant (SS $6.34 \pm 1.49 \mathrm{~F}$ and $p=0.2254$ ). This suggests that the intervention had a positive effect on the understanding of concepts dealing with dissolving of salts. This improved achievement was due to the impact of POE strategy which reduced learners' misconceptions regarding dissolving of salts. Learners in EG seem to have undergone a conceptual change in their understanding of dissolved salts. These results are in agreement with that of White and Gunstone (1992) and Sesen (2013) where conceptual change had positive results and misconceptions were significantly reduced. The results obtained in this study also corroborated that of Tomita and Yin (2007) and Hubber (2005) in their study about diagnosing and dealing with learners' misconceptions in floating and sinking objects.

\section{Conclusions and Recommendations}

This study revealed that the use of POE strategy has a positive effect on learners' misconceptions about dissolved salts. As a result of this strategy, learners were able to overcome their initial misconceptions and improved on their performance. Also, two new misconceptions were identified, namely: 1) salts dissolve in water when it is in 'fine' grains; and, 2) solid sodium chloride is not an ionic compound. The implication of these results is that science educators, curriculum developers, and textbook writers should work together to include elements of POE in the curriculum as a model for conceptual change in teaching science in schools. Educators should also encourage learners to move from the macro to micro level during their explanations of dissolving salts and other chemical reactions in science. It is recommended that a similar study is undertaken to determine the effect of the POE strategy on other science concepts.

\section{References}

Arizona Facilities Council (AFC). (2000). Definition of learner centered education. http://www.abor.asu.edu/4-special-programs/lce/afcdefined-Ice.htm, Retrieved, August 06, 2008.

Assessment Resource Banks. (2007). Predict, Observe, Explain (POE). http://arb.nzcer.org.nz Inzcer3/strategies/poe.htm, Retrieved March 03, 2007.

Auwal, A. (2013). Effects of teaching method on retention of Agricultural Science knowledge in

senior secondary schools of Bauchi Local Government Area, Nigeria. International Journal of Science and Technology Educational Research, 4(4), 63-69.

Brodie, K., Lelliott, T., \& Davis, H. (2002). Developing learner centred practices through the FDE programme. In J. Adler \& Y. Reed (Eds.), Challenges of teacher development: An investigation of take-up in South Africa (pp. 94-117). Pretoria: Van Schaik.

Brookes, D., Alant, B., Gibbon, D., Nkopodi, N. \& Patrick, M. (2005). OBE for FET Physical Sciences Grade 10, Learners Book. Cape Town, Nasou Via Afrika.

Cosgrove, M. R. \& Osborne, R. (1981). Physical change: A working paper of the Learning in Science Project (no. 26) University of Waikato, Hamilton, New Zealand.

DoE (2003). National Curriculum Statement Grades 10 - 12 (General) - Physical Sciences. Sol Plaatjie House, Pretoria.

de la Harpe, B., \& Thomas, I. (2009). Curriculum change in universities: Why education for sustainable development is so tough. Journal 
of Education for Sustainable Development, 3, 75-85.

Demircioglu, G., Ayas, A. \& Demircioglu, H. (2005). Conceptual change achieved through a new teaching program on acids and bases. KTU Faith Education Faculty, Department of Secondary Science Education, Sogutlu Mevkii 61335, Akcaabat/TRABZON,Turkey.http:// www.rsc.org/ Education/CERP/issues/2005-1/conceptual.asp. Retrieved April 10, 2009.

Duit, R., Treagust, D. F. \& Mansfield, H. (1996). Investigating students understanding, as a prerequisite to improve teaching and learning in science and mathematics. New York: Columbia University Teachers College Press.

Hapkiewicz, A. (1999). Naĩve Ideas in Earth Science. MSTA Journal. 44(2), 26-30.

Holdsworth, S., Bekessy, S., Mnguni, P., Hayles, C., \& Thomas, I. (2006). Beyond leather patches: Sustainability education at RMIT University, Australia. In W. L. Filho (Ed.), Innovation, education and communication for sustainable development (pp. 153-176). Frankfurt, Germany: Lang Publishing.

Hewson, P. W. (1981). A conceptual change approach to learning Science. European Journal of Science Education, 3, 383-396.

Hewson, M. G. \& Hewson, P. W. (2003). Effect of instruction using students' prior knowledge And Conceptual Change Strategies On Science Learning. Journal of Research In Science teaching. 20 (8), 731-744.

Hubber, P. (2005). Explorations of year 10 students' conceptual change during instruction. Asia-Pacific forum on Science Learning and Teaching, 6 (1) article 1. http://www.ied.edu.hk /apfslt/ v6 issue1/hubber/index.htm Accessed June 26, 2012.

Kala, N., Yaman, F. \& Ayas, A. (2013). The Effectiveness Of Predict-Observe-Explain Technique In Probing Students' Understanding About Acid-Base Chemistry: A Case For The Concepts Of Ph, Poh, And Strength. International Journal of Science and Mathematics, 11(3), 555-574.

Kasanda, C. D., Lubben, F., Campbell, B., Kapenda, H. M., Kandjeo-Marenga, H. U. \& Gaoseb, N. (2003). Learner-Centered TeachingThe Rhetoric and Practice, The Case of Namibia. In: Putsoa, B., Dlamini, M., and Kelly, V (Eds). Proceeding of the 11th Annual SAARMSTE Conference. SAARMSTE: Mbabane, pp. 457.

Koba, S. \& Tweed, A. (2009). Hard-to-Teach Biology Concepts: A Framework to Deepen Student Understanding. Arlington, VA: National Science Teachers Association Press.

Kurt, H, Ekici, G, Aktaş, M. \& Aksu, Ö. (2013). On the concept of "Respiration": Biology student teachers' cognitive structures and alternative conceptions. Educational Research and Reviews, 8(21), 2101-2121.

Lee, O. (2002). Promoting Scientific Inquiry With Elementary Students from Diverse Cultures and language. Review of Research in Education, 26, 23-70.

Mpofu, N. V. (2006). Grade 12 students' conceptual understanding of chemical reactions: A case study of fluoridation. A thesis submitted in partial fulfilment of the requirements for Masters in Education. University of the Western Cape.

Mumba, F., Rollnick, M. \& White, M. (2002). How wide is the gap between high school and first year university chemistry at the University of the Witwatersrand. South African Journal of Higher Education, 16(3), 148-157.

Ogunniyi, M. B. (1999). Chemical change: Assessment of grades 7-9 Pupils Knowledge and Interest in Science and Technology. Cape Town, RSA: School of Science and Mathematical Education, University of the Western Cape.

Piaget, J. (1970). Structuralism. New York: Basic Books.

Piaget, J. \& Inhelder, B. (1974). The child's construction of quantities. Routledge and Kegan Paul: London.

Picower, B. (2012). Practice what you teach: Social justice education in the classroom and the streets. New York, NY: Routledge.

Picower, B. (2013). You Can't Change What You Don't See: Developing New Teachers' Political Understanding of Education. Journal of Transformative Education, http://jtd.sagepub.com/content/ early/2013/07/17/1541344613502395

Parker, J. M., Anderson, C. W., Heidemann, M., Merrill, J., Merritt, B., Richmond, G. \&

Urban-Lurain, M. (2012). Exploring Undergraduates' Understanding of Photosynthesis Using Diagnostic Question Clusters. CBE Life Science Education, 11(1): 47-57.

Posner, G. J., Strike, K. A. \& Hewson, P. W. (1982). Accommodation of a scientific conception: towards conceptual change. Science Education, 66, 211-227.

Potgieter, M, Rogan, J. M. \& Howie, S. (2005). Chemical Concepts Inventory of Grade 12 learners and UP foundation year students. African Journal of Research in Mathematics, Science and Technology Education, 9 (2): 121-134.

Richmond, A. S. \& Cummings, R. (2005). Implementing Kolb's learning styles into online distance education. International Journal of Technology in Teaching and Learning, 1(1), 45-54.

Sesen, B. A. (2013). Diognosing pre-service teachers' understanding of chemistry concepts by using coputer-mediated predict-observeexplain tasks. Chemistry Education research and Practice, 14, 239-246.

Spillane, J. P. (2005). Distributed leadership. Educational Forum, 69, 143-150. Retrieved from http://proquest.umi.com/ pqdweb? index=25\&did=784756091\&SrchMode=1\&sid=2\&Fmt=6\&VInst=PROD\&amp;VType=PQD\&RQT=309\&VName=PQD\&TS=12850 44490\&clientld $=16532$

Svandova, K. (2013). Lower secondary school pupils misconceptions about photosynthesis and plant respiration: Pilot study. ECER 2013, Creativity and Innovation in Educational Research.

Tanner, K. \& Allen, D. (2005). Approaches to Biology Teaching and Learning: Understanding the Wrong Answers - Teaching Toward Conceptual Change. Cell Biology Education, 4(2), 112-117.

Tomita, M. \& Yin., Y. (2007). Promoting conceptual change through formative assessment in the Science classroom. Paper presented at the Hawaii Educational Research Association annual conference, Honolulu.

Vygotsky, L. (1986). Thought and language. Cambridge, MA: MIT Press.

Walker, S. (2001). GIS and students as scientists: Constructivist approaches to science curriculum restructuring in-service supplement. 
San Antonio, Texas: Our Lady of the Lake University, Education Department. Available: http://education.ollusa.edu/edtech leduc6306s1/reading /GIS and student as scientists inservise supplement .pdf Retrieved May 14, 2010.

Wenger, E. (1998). Communities of practice: Learning, meaning, and identity. Cambridge,UK: Cambridge University Press.

White, R. T. \& Gunstone, R. F. (1992). Probing Understanding. Great Britain: Falmer Press.

Willink, K.G. \& Jacobs, J. M. (2013). Teaching for change: articulating, profiling, and assessing transformative learning through communicative capabilities. Journal of Transformative Education, 9(3) 143-164.

\section{Appendix 1}

\section{Worksheet No. 1}

\section{How Salts are Formed}

Salt is the product of acid-base reactions. It is formed when appropriate base, metal, metal oxide or carbonate reacts with an acid. When an acid reacts with a base, salts and water are formed

\section{Three ways of salt formation}

1. Neutralization

2. Direct combination

3. Reaction of metal oxides and acids

\section{Formation of salts}

Use $\mathrm{HCl}$ and metal of group $1(\mathrm{~K}, \mathrm{Na})$ and $2(\mathrm{Ca})$ to predict salts that can be formed.

\section{Write the chemical equation as:}

Acid + Metal $\rightarrow$ Salt

Acid + Metal hydroxide $\rightarrow$ Salt

Acid + Carbonate $\rightarrow$ Salt

Acid + Base $\rightarrow$ Salt

Discussion (Learners + Educator) on the above activity for correcting learners.

Complete the following equation as a way of depicting which salts will be formed
1. $\mathrm{K}+\mathrm{Cl} \rightarrow$
2. $\mathrm{Na}+\mathrm{HCl} \rightarrow$
3. $\mathrm{Ca}+\mathrm{Cl} \rightarrow$
4. $\mathrm{NaOH}+\mathrm{HNO}_{3} \rightarrow$
5. $\mathrm{CaCO}_{3}+\mathrm{HCl} \rightarrow$
6. $\mathrm{MgO}+\mathrm{HCl} \rightarrow$
7. $\mathrm{NaOH}+\mathrm{H}_{2} \mathrm{~S} \rightarrow$

\section{Worksheet No. 2}

\section{Ionisation of Salts}

Some molecular compounds produce ions their solution - thus they undergo ionization in water for example

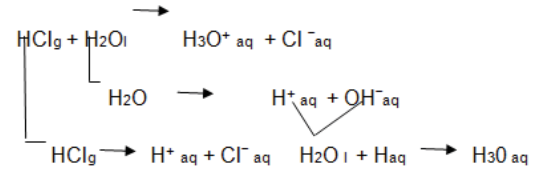

Write down the corresponding ions of the chemicals below
1. $\mathrm{HCl} \rightarrow$
2. $\mathrm{NaCl} \rightarrow$
3. $\mathrm{CaCl}_{2} \rightarrow$
4. $\mathrm{NaNO}_{3} \rightarrow$
5. $\mathrm{MgCl}_{2} \rightarrow$
6. $\mathrm{Na}_{2} \mathrm{SO}_{4} \rightarrow$
7. $\mathrm{KCl} \rightarrow$ 


\section{Worksheet No.3}

\section{How salts dissolve in water}

Because water molecules are polar, they can interact strongly with ions of ionic compounds such as sodium chloride

The $\mathrm{a}^{+}$ends of water molecules attract the $\mathrm{Cl}^{-}$ions on the surface of the solute, and the a - ends of water attract the $\mathrm{Na}^{+}$ions.

These attractions help to overcome the electrostatic attraction between the $\mathrm{Na}^{+}$and $\mathrm{Cl}^{-}$ions in the solid. $\mathrm{The}^{-} \mathrm{Na}^{+}$and $\mathrm{Cl}^{-}$ions move into solution surrounded by water molecules.

This process is called hydration

NB: In some ionic solids, the attraction between ions is strong enough to prevent them from dissolving in water. Hence some salts do not dissolve in water.

\section{Class Activities (POE Activities, group work)}

\section{Activity 1}

Materials needed

- Water

- Transparent container (glass or plastic)

- $\quad$ Fine $\mathrm{NaCl}, \mathrm{NaNO}_{3}, \mathrm{KCl},\left(\mathrm{NH}_{4}\right)_{2} \mathrm{SO}_{4}, \mathrm{AgCl}, \mathrm{Pb}\left(\mathrm{SO}_{4}\right)_{2}, \mathrm{Na}_{2} \mathrm{CO}_{3}, \mathrm{CaCO}_{3}$

Predictions: What will happen if $\mathrm{NaCl}$ is added to water and why?

Group prediction (discussed and agreed upon)

\section{Prediction testing}

\section{Steps to be followed}

Each group takes water in the container.

Add a few particles of the salt you have in your group (you may stir if necessary).

Observe and explain what happens

\section{Activity 2}

Materials needed

- $\quad$ Transparent container (glass or plastic)

- Marbles (plenty of mables)

- Sand

- Measuring cups

Prediction: what will happen if you pour mables first and the sand into the same container?

Group prediction: (discussed and agreed upon)

\section{Predicting testing}

Steps to be followed

Fill the container up to the brim with marbles. Will it be possible to add any other materials to this full container? Explain.

Add sand to the container with marbles (shake to settle the sand in between the marbles). Explain your observation.

Explain why it was possible for the container to hold the added amount of sand?

(Measure off the amount of sand added to the marbles (by measuring how much is left over in a measuring cup).

NB: Be aware that marbles and sand is only illustrating how molecules of matter behave and that they are not molecules themselves, they are only used as models.

Explain

Student explore questions in the group discussion template below 


\section{Group discussion template}

Why the container filled with marbles could still hold the added sand?

Could we have started with sand and then marble? Explain what difference it makes?

What would you infer about the size of molecules of different materials or substances?

\section{Activity No. 3}

Materials needed

- A transparent container (glass or plastic)

- Marbles (plenty of marbles)

- Sand

- Water

- Measuring cups

Prediction: What will happen if you pour sand first and then marbles into same container?

Group prediction: (discussed and agreed upon)

\section{Prediction testing}

Steps to be followed

Fill the container up to the brim with sand. Will it be possible to add any other materials to this full container? Explain.

(Add marbles to the container with sand and shake the container).

Explain your observation.

Explain why it was not possible for the container to hold the added amount of the marbles?

\section{Appendix 2}

Pre/Post Test

Question 2

State whether the Following Statements are True or False. If the answer is FALSE, provide the correct statement.

1.1. A salt is formed when the appropriate base, metal, metal hydroxide or carbonate reacts with an acid.

1.2. All salts can dissolve in water.

1.3. Salts are ionic compounds.

1.4. When salts dissolve in water they form ions.

1.5. An example of an ionic compound formed when salts dissolve in water is:

Multiple-Choice Questions

$\mathrm{KCl}_{(\mathrm{s})} \leftrightarrow \mathrm{K}^{+}{ }_{(\mathrm{aq})}+\mathrm{Cl}_{(\mathrm{aq})}$

2.1. When acids react with metals they form
A. bases
B. water
C. salts

2.2. Which formula represents a salt?
A. $\quad \mathrm{KCl}$
B. $\quad \mathrm{NaNO}_{3}$
C. $\mathrm{MgCO}_{3}$ 
2.3. Which salt cannot dissolve in water?
A. $\quad \mathrm{AgCl}$
B. $\quad \mathrm{NaCl}$
C. $\mathrm{KCl}$

2.4. The following salt can be formed through neutralization of an acid and a base
A. $\quad \mathrm{NaCl}$
B. $\quad \mathrm{Ca}\left(\mathrm{NO}_{3}\right)_{2}$
C. $\quad \mathrm{NH}_{4} \mathrm{Cl}$

2.5. Through direct combination of some substances the following salt can be formed
A. $\mathrm{NaCl}$
B. $\mathrm{Ca}\left(\mathrm{NO}_{3}\right)_{2}$
C. $\quad \mathrm{NH}_{4} \mathrm{Cl}$

2.6. Through the reaction of metal oxide and acid the following salt can be formed
A. $\quad \mathrm{NaCl}$
B. $\quad \mathrm{Ca}\left(\mathrm{NO}_{3}\right)_{2}$
C. $\quad \mathrm{NH}_{4} \mathrm{Cl}$

2.7. Which equation represents the dissociation of $\mathrm{NaCl}$ ?
A. $\quad \mathrm{NaCl}_{(\mathrm{s})} \leftrightarrow \mathrm{Na}^{-}{ }_{(\text {aq })}+\mathrm{Cl}^{+}{ }_{(\mathrm{aq})}$
B. $\mathrm{NaCl}_{(\mathrm{s})} \leftrightarrow \mathrm{Na}^{+}(\mathrm{aq})+\mathrm{Cl}_{(\text {(aq) }}$
C. $\mathrm{NaCl}_{(\mathrm{s})} \leftrightarrow \mathrm{Na}+\mathrm{Cl}_{(\mathrm{aq})}$

2.8. The diagram below represents a mixture of $\mathrm{H}_{2} \mathrm{O}$ and $\mathrm{NaCl}$ in a closed container.

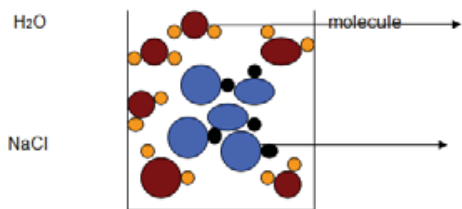

2.9. Which diagram shows the results after the mixture reacts as completely as possible according to the equation $\mathrm{NaCl}_{(\mathrm{s})}+\mathrm{H}_{2} \mathrm{O}$ $\leftrightarrow \mathrm{Na}^{+}{ }_{(\mathrm{aq})}+\mathrm{Cl} \cdot(\mathrm{aq})$. Give a reason for your choice.
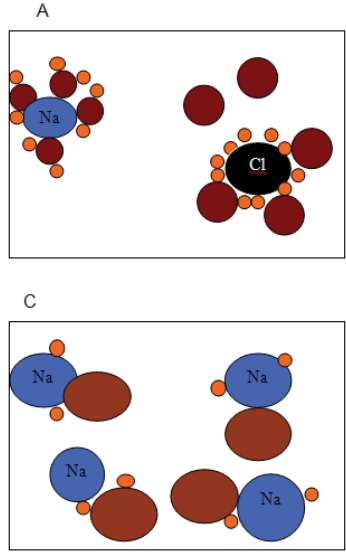

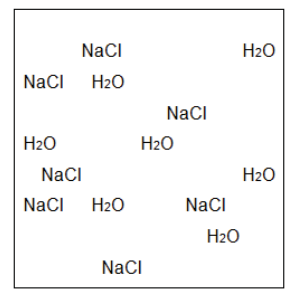

Question 3

3.1. In your own view what happens when salt like $\mathrm{NaCl}$ dissolve in water. Use a diagram/s and chemical equation/s to support your opinion.

3.2. Some salts does not dissolve in water. In your own view what happens when a salt do not dissolve in water. You may use diagram/s and chemical equation/s to support your opinion. 